UDC: 37.01:796

DOI: $10.26697 /$ ijes.2019.2.25

\section{Developmental Assets in Physical Education}

Senior Lecturer Yurko N. A. ${ }^{1}$, Associate Professor Romanchuk O. V. ${ }^{1}$, Associate Professor Protsenko U. M.

${ }^{1}$ Lviv State University of Physical Culture named after Ivan Boberskyi, Ukraine

\begin{abstract}
Background:

There are no simple answers about how to improve education for all students. Research and practice show that no single strategy or program makes all the difference. While there have been encouraging innovations and studies, none has accounted for significant, large-scale improvements.

There is growing evidence, though, that asset-based approaches to education and youth development have tremendous potential to contribute to the academic success of students. Thus, educational establishments are in charge of not only students' intellectual development, but of their personal, social, emotional, and physical development as well.

On the grounds of the introductory considerations, the research aims at examining the main developmental assets in terms of physical education.
\end{abstract}

\section{Results:}

A variety of analyses reveal that higher levels of developmental assets are consistently related to a variety of measures of student achievement. Search Institute's research on developmental assets adds to the findings that suggest building developmental assets to be a critical component of boosting student achievement. Developmental assets may also serve as boost for students to be successful in their overall growth and development.

An emphasis on overall development may have as much or more positive impact on academic outcomes as the traditional strategies, such as emphasizing task mastery, requiring higher teacher certification standards, and using high-stakes testing to track achievement. Further, asset building may enhance or multiply the impact of these and other strategies. Thus, building developmental assets does not replace those efforts, but focuses on human development as a core process in promoting student achievement.

The research analysis of developmental assets in physical education reveals the outcomes to be as follows.

- Support. Educators are in a great position to provide the support that students need. Be it in physical education or within the community, it is significant to notice the students being good and praise them for it.

- Empowerment. Physical educators should believe, value and empower their students, and do their best to always see the students as resourceful, knowledgeable and capable of reaching their goals in a safe environment.

- Boundaries and expectations. Clear rules and academic responsibilities need to be outlined and coconstructed between students and their physical educator to ensure a consistent and engaging learning environment.

- Constructive use of time. Physical education needs to promote constructive activity. It is necessary to develop lesson plans and programming that will encourage active lifestyles and community involvement.

- Commitment to learning. Within the physical education experiences it is vital to find ways for students' motivation to learn. Homework and special tasks should be appropriately engaging and interesting to the students.

- Social competencies. Interpersonal competencies can be fostered through physical education teacher exposing students to opportunities for collaboration and communication, particularly through cooperative games.

- Positive identity. Physical educators should make their students feel like they have some power through leading the group stretch or setting up the badminton nets. This allows students to gain a sense of personal belonging.

\section{Conclusions:}

Academic achievement and personal development are complementary and mutually supportive. Therefore, educational institutions must be responsible not just for students' intellectual development, but also for their personal, social, emotional, and physical development. It is vital to build their self-esteem by creating purposeful physical education experiences. When students derive a sense of purpose from the physical education lessons, they begin to see activity and movement as a lifelong principle.

\section{Information about the authors:}

Yurko Nadiia Anatoliivna - Senior Lecturer of the Department of Ukrainian and Foreign Languages, Lviv State University of Physical Culture named after Ivan Boberskyi, Lviv, Ukraine.

Research interests: language and linguistics, physical education and sport, tourism and hospitality; https://orcid.org/0000-0001-7077-2442.

Romanchuk Olha Vasylivna - Doctor of Philosophy in Philology, Associate Professor; Head of the Department of Ukrainian and Foreign Languages, Lviv State University of Physical Culture named after Ivan Boberskyi, Lviv, Ukraine.

Research interests: language and linguistics, physical education and sport, tourism and hospitality; https://orcid.org/0000-0001-8215-9741.

Protsenko Uliana Mykolaivna - Doctor of Philosophy in Pedagogy, Associate Professor of the Department of Ukrainian and Foreign Languages, Lviv State University of Physical Culture named after Ivan Boberskyi, Lviv, Ukraine.

Research interests: language and linguistics, physical education and sport, tourism and hospitality; https://orcid.org/0000-0001-8180-6433.

\section{Corresponding Author:}

Yurko Nadiia Anatoliivna

Corresponding Author's Email: nau40279@gmail.com 